\title{
A Slow Pyrolysis Biochar Derived from Tetrapanax papyriferum Petiole as an Effective Sorbent for Removing Copper ions from Aqueous Solution
}

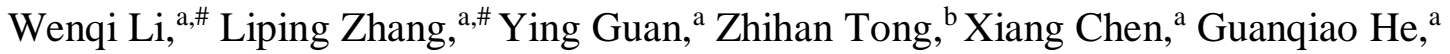 \\ and Hui Gao ${ }^{\text {a,* }}$ \\ Biochar derived from Tetrapanax papyriferum petioles at different pyrolysis \\ temperatures was used to remove copper from aqueous solution. Abundant \\ porous structures were observed with scanning electron microscopy, and \\ transmission electron microscope images revealed a unique layered nanopore \\ structure. A high pyrolytic temperature resulted in a biochar with a higher surface \\ area, ash content, and mineral element content. The maximum adsorption \\ capacity of $T$. papyriferum petiole biochar (TBC) was $182 \mathrm{mg} / \mathrm{g}$. The Langmuir \\ adsorption isotherm model and pseudo-second-order kinetics model were most \\ suitable for describing the adsorption process, indicating that adsorption takes \\ place at specific homogeneous sites within the adsorbent. The calculated $\Delta H^{\circ}$ \\ values indicated that the adsorption process was endothermic. The adsorption \\ mechanism for TBC was attributed to precipitation, ion exchange, C-m \\ interactions, and complexation. Thus, the biochar used in this study is a \\ promising environmentally friendly and effective adsorbent for removing $\mathrm{Cu}^{2+}$ \\ ions from an aqueous solution.
}

Keywords: Tetrapanax papyriferum; Biochar; Heavy metals; Adsorption; Isotherms

Contact information: a: School of Forestry and Landscape Architecture, Anhui Agricultural University, Hefei 230036, China; b: College of Materials Science and Engineering, Northeast Forestry University, Harbin 150040, China; *Corresponding author: huigaozh@163.com

\#: These authors contributed equally to this study.

\section{INTRODUCTION}

Tetrapanax papyriferum (Family: Araliaceae) is native to northern Formosa and to the South China provinces of Hunan, Szechwan, Yunnan, Kweichow, Kwangsi, and Kwangtung. Under natural conditions, it is usually a shrub 3.0 to 6.0 feet tall but may attain a height of 30.0 feet (Ho et al. 2005). Tetrapanax papyriferum has large leaves. The diameter of the lamina is $55.0 \pm 1.1$ to $85.0 \pm 1.2 \mathrm{~cm}$, and the average length and diameter of its petiole is $70.0 \pm 2.0$ to $90.0 \pm 3.5 \mathrm{~cm}$ and $0.8 \pm 0.2$ to $1.6 \pm 0.4 \mathrm{~cm}$, respectively. The petiole of $T$. papyriferum is hollow, and a white layer lies close to the inner wall. Furthermore, T. papyriferum has many special characteristics, such as low wood density, extremely fast growth, short felling period, wide adaptability, and strong self-reproduction ability. However, far too little attention has been paid to its potential applications. Tetrapanax papyriferum is inefficiently used and is not recycled. It has even been considered an invasive species in some places. In China, the stalk pith of $T$. papyriferum is a famous traditional Chinese medicine that is produced annually, but the leaves are discarded, resulting in serious waste. The comprehensive utilization of $T$. papyriferum, including its lamina and stalk, has become an increasingly challenging issue.

Large quantities of heavy metal ions bioaccumulate throughout the food chain, 
where they threaten human health (Mishra et al. 2012; Lin et al. 2017b; Teodoro et al. 2017). Copper is an essential trace element that is not easily degraded. Many diseases, such as stomach and intestinal disorders, occur in humans when copper is ingested in excess (Lin et al. 2017a). Thus, efficient techniques are necessary to eliminate heavy metal ions from wastewater. There are many techniques for removing heavy metal ions (Lin et al. 2017a; Niu et al. 2017; Ren et al. 2017), including physical, chemical, and biological methods, such as chemical precipitation, ion exchange, adsorption, membrane filtration, and solvent extraction. Data from several studies suggests that adsorption is a highly efficient, cost-effective, and simple technique to remove heavy metal ions with minimal production of secondary pollution (Zhang et al. 2018a, b).

The most widely used class of adsorbents is carbon-based absorbents. Biochar (BC) is a carbon-rich solid derived from the thermal degradation of plant residue and agricultural waste in an oxygen-limited environment (Vyavahare et al. 2018). Biochar has been prepared from various feedstock materials, such as wood, sugarcane, rice husk, bamboo, dairy manure, and bioenergy residue (Li et al. 2017; Xu et al. 2017; Vyavahare et al. 2018). A great deal of research on biochar has focused on its adsorption of heavy metal ions (Han et al. 2016; Park et al. 2016; Qian et al. 2016). Idrees et al. (2018) used guinea fowl manure derived biochar and cattle manure derived biochar to adsorb $\mathrm{Cu}^{2+}$ ions, and the maximum sorption capacity values were 46.6 and $44.5 \mathrm{mg} / \mathrm{g}$, respectively. Zhou et al. (2017) investigated the adsorption of $\mathrm{Cu}^{2+}$ ions using biochar derived from earthworm manure at different pyrolysis temperatures. The adsorption capacity was 24.27 mg/g. Kim et al. (2016) prepared KOH-activated Enteromorpha compressa biochars to investigate the removal efficiency of $\mathrm{Cu}^{2+}$ ions from an aqueous solution. The adsorption capacity of $\mathrm{Cu}^{2+}$ ions was $137 \mathrm{mg} / \mathrm{g}$. Biochar is a low-cost adsorbent with high specific surface area and a high capacity to adsorb heavy metal ions. Thus, biochar is a promising alternative agent for removing heavy metal ions. The adsorption capacity of a biochar depends highly on its physicochemical properties, such as surface area, pore properties, and elemental constitution. The physicochemical properties of a biochar depend upon the raw material, pyrolysis temperature, environment (limited oxygen or $\mathrm{N}_{2}$ ), and the heating rate. Hence, selection of the feedstock and pyrolysis conditions has an important impact on the final sorption properties of a biochar.

Tetrapanax papyriferum grows and reproduces at a very high rate and is considered an invasive plant species in some locations. No previous study has investigated adsorption of heavy metal ions using a biochar derived from $T$. papyriferum. Thus, this inexpensive and readily available waste biomass was used to remove $\mathrm{Cu}^{2+}$ ions from wastewater. In this study, a new low-cost biochar adsorbent derived from $T$. papyriferum petioles was prepared at different temperatures and used to remove $\mathrm{Cu}^{2+}$ ions. This study evaluated the absorption behavior of $\mathrm{Cu}^{2+}$ ions in T. papyriferum petiole biochar (TBC) under different pyrolysis conditions. The biochars were characterized via elemental analysis, the Brunauer-Emmett-Teller (BET) method, Fourier transform infrared spectroscopy (FT-IR), X-ray diffraction (XRD), scanning electron microscopy (SEM), X-ray photoelectron spectrometry (XPS), transmission electron microscopy (TEM), and atomic absorption spectroscopy (AAS). Batch experiments were conducted for different factors, such as initial $\mathrm{pH}$, contact time, concentration of $\mathrm{Cu}^{2+}$ ions, and temperature. 


\section{EXPERIMENTAL}

\section{Materials}

Tetrapanax papyriferum was planted at Anhui Agricultural University (Anhui, China), and its petioles were used as the raw material in this study. The mature petioles of $T$. papyriferum were harvested, cleaned, air-dried, and cut into $5 \mathrm{~cm}$ lengths for the biochar samples. $\mathrm{CuSO}_{4} \cdot 5 \mathrm{H}_{2} \mathrm{O}$ was purchased from Sinopharm Chemical Reagent Co., Ltd. (Shanghai, China). Deionized water $\left(18 \mathrm{M} \Omega \cdot \mathrm{cm}^{-1}\right)$ was prepared using a Milli-Q purification system from Kertone (Changsha, China).

\section{Methods}

Preparation of the biochars

The air-dried samples were pyrolyzed in a tubular vacuum furnace (BTF-1200C-II, BEQ, Anhui, China) under a $\mathrm{N}_{2}$ atmosphere. The samples were heated from room temperature to $500,600,700$, or $800{ }^{\circ} \mathrm{C}$ at a rate of $5{ }^{\circ} \mathrm{C} \cdot \mathrm{min}^{-1}$, and the temperature was held for $2 \mathrm{~h}$. The temperature of the samples decreased to room temperature at a rate of $5{ }^{\circ} \mathrm{C} \cdot \mathrm{min}^{-1}$. Finally, the biochars were sieved through 200 mesh. The resulting biochars were named TBC-500, TBC-600, TBC-700, and TBC-800.

\section{Characterization of the biochars}

$\mathrm{C}, \mathrm{H}$, and $\mathrm{N}$ contents were measured with a CHN Elemental Analyzer (Vario EL Cube, Elementar, Langenselbold, Germany). The percentage of oxygen in each sample was estimated by mass difference ( $100 \%$ minus the percent of $\mathrm{C}, \mathrm{H}, \mathrm{N}$, and ash). The biochar ash was obtained by heating the samples to $800{ }^{\circ} \mathrm{C}$ for $2 \mathrm{~h}$ in a muffle furnace (Wang et al. 2016). The elemental contents (e.g., $\mathrm{Ca}, \mathrm{Mg}, \mathrm{Fe}, \mathrm{K}, \mathrm{Cu}, \mathrm{Mn}$, and $\mathrm{Zn}$ ) were analyzed using AAS (TAS-990, Pgeneral, Beijing, China) (Tong et al. 2011). The surface areas of the biochars were measured with a surface area analyzer (BET, ASAP20, Micromeritics Inc., Norcross, GA, USA) using the $\mathrm{N}_{2}$ adsorption method. The FT-IR spectra of the samples were measured with a Nicolet 6670 spectrometer (Thermo Fisher, Waltham, MA, USA) in the range of 4,000 to $400 \mathrm{~cm}^{-1}$ with a resolution of $2 \mathrm{~cm}^{-1}$. The XRD measurements were performed with an XRD-3 diffractometer (PERSEE, Beijing, China) using $\mathrm{Cu} \mathrm{K \alpha}$ radiation and an X-ray wavelength of $0.15406 \mathrm{~nm}$ at $36 \mathrm{KV}$ and 20 $\mathrm{mA}$. X-ray photoelectron spectrometry (XPS) data was obtained with an ESCALAB 250Xi electron spectrometer (Thermo Fisher). The morphology of each sample was observed via field emission SEM (S-4800, Hitachi, Tokyo, Japan) with the samples being sputter coated with gold. Several drops of the diluted suspension were deposited onto a freshly cleaved mica substrate and allowed to dry. Dispersibility of the biochar was investigated by TEM using the HT7700 (Hitachi, Japan) instrument. The pH of each sample was measured with a $\mathrm{pH}$ meter (Rex PHS-25, Shanghai, China) at a ratio 1:20 $(\mathrm{m} / \mathrm{V}, \mathrm{g} / \mathrm{mL})$ sample: water.

\section{Batch adsorption experiments}

A $1,000 \mathrm{mg} / \mathrm{L}$ solution of $\mathrm{Cu}^{2+}$ ions was prepared by accurately dissolving weighed $\mathrm{CuSO}_{4} \cdot 5 \mathrm{H}_{2} \mathrm{O}$ in distilled water, and other experimental solutions were obtained by dilution. The concentration of $\mathrm{Cu}^{2+}$ ions was determined by AAS (TAS-990, Pgeneral, Beijing, China). Batch adsorption experiments were performed to remove the $\mathrm{Cu}^{2+}$ ions from a $15 \mathrm{~mL}$ solution of $\mathrm{Cu}^{2+}$ ions. The initial $\mathrm{pH}$ of the heavy metal solution was adjusted using $0.1 \mathrm{M} \mathrm{HCl}$ and $0.1 \mathrm{M} \mathrm{NaOH}$ solutions. A $15 \mathrm{~mL}$ aliquot of $\mathrm{Cu}^{2+}$ ion 
solution was mixed with $40 \mathrm{mg}$ of adsorbent in a $50 \mathrm{~mL}$ centrifuge tube and shaken at $180 \mathrm{rpm}$ and $30{ }^{\circ} \mathrm{C}$. The effects of initial metal ion concentration $(25$ to $1,000 \mathrm{mg} / \mathrm{L}$, adsorption time $24 \mathrm{~h}$ ) and contact time (10 to $120 \mathrm{~min}$ ) on adsorption performance were investigated in the batch mode of operation. The effects of various temperatures on the removal capacity of the adsorbent were also studied.

The amount of heavy metal adsorbed per unit mass of the adsorbent $\left(Q_{e}\right)$ was calculated using the following mass balance equation,

$$
Q_{e}=\left(C_{0^{-}} C_{e}\right) \times(V / m)
$$

where $C_{0}$ and $C_{e}$ are the initial and equilibrium concentrations of $\mathrm{Cu}^{2+}$ ions $(\mathrm{mg} / \mathrm{L})$, respectively; $V$ is the volume of solution $(\mathrm{L}) ; m$ is the weight of the dry biochars $(\mathrm{g})$; and $Q_{e}$ is the adsorption capacity of the adsorbent for $\mathrm{Cu}^{2+}$ ions $(\mathrm{mg} / \mathrm{g})$.

\section{Reutilization of TBC biochar}

Briefly, in the first sorption cycle, $40 \mathrm{mg}$ of the adsorbent was mixed with $15 \mathrm{~mL}$ of $150 \mathrm{mg} / \mathrm{L}(\mathrm{pH}=5) \mathrm{Cu}^{2+}$ ion solution and shaken at $30{ }^{\circ} \mathrm{C}$ for $12 \mathrm{~h}$. The successfully adsorbed $\mathrm{Cu}^{2+}$ ions from the first cycle were separated with a $0.45 \mu \mathrm{m}$ filter and washed with distilled water. After drying, the adsorbent was reutilized for the next three cycles of $\mathrm{Cu}^{2+}$ ion sorption. This experiment investigated the recycling performance of the TBC.

\section{RESULTS AND DISCUSSION}

\section{Characterizations of the Biochars}

The SEM and TEM images of the biochars are presented in Fig. 1. An abundant number of pores was detected in the structures in Fig. 1, but the pore structures and pore sizes were irregular and heterogeneous. The TEM images of TBC provided further detailed structural information, revealing a unique stacked and multi-layered morphology with a layered nanopore structure and bulky aggregation. Undoubtedly, the pore structure provided more usable surface area causing higher adsorption of heavy metals.

The nitrogen adsorption-desorption isotherms and the pore size distribution of the biochars are shown in Fig. 2. The $\mathrm{N}_{2}$ adsorption-desorption can provide preliminary qualitative information on the adsorption mechanism and on the porous structure of the carbons. Figure 2 shows a representative $\mathrm{N}_{2}$ adsorption-desorption isotherm and the corresponding Barrett-Joyner-Halenda $(\mathrm{BJH})$ pore size distribution curve. The adsorption-desorption isotherm plot of TBC-500 and TBC-600 represents a Type III (non-porous multi-layer adsorption) isotherm. The BET surface areas of the TBC-600 and TBC-500 were 3.82 and $1.81 \mathrm{~m}^{2} / \mathrm{g}$, respectively. The isotherm plot of TBC-700 shows a hysteresis which implies the existence of the open channel in biochar structure. For the TBC-700, the $\mathrm{N}_{2}$ isotherms were of type IV, with type- $\mathrm{H}_{4}$ hysteresis loops, which implies the existence of micro- and mesoporous structures in the TBC-700, and narrow cracks and pores in the sorbent materials. Then the isotherm plot of TBC-800 resembles Type II isotherm (non-porous, mono to multi-layer adsorption). The Type II sorption curves are associated with micro and mesoporous solids. The fast-growing nitrogen adsorption curves indicated molecular monolayer adsorption or microporous multilayer adsorption. The surface area was dramatically increased from $1.81 \mathrm{~m}^{2} / \mathrm{g}$ to $236.4 \mathrm{~m}^{2} / \mathrm{g}$ when the pyrolysis temperature was increased to $800{ }^{\circ} \mathrm{C}$, indicating an increase in the extent of raw material cracking and gradual development of the pore structure. The BET surface areas 
of the TBC $\left(800,700,600\right.$, and 500) were $236.4,207.3,3.8$, and $1.8 \mathrm{~m}^{2} / \mathrm{g}$, respectively. The BET surface area of TBC increased sharply from $1.8\left(500{ }^{\circ} \mathrm{C}\right)$ to $236.4 \mathrm{~m}^{2} / \mathrm{g}$ $\left(800{ }^{\circ} \mathrm{C}\right)$, indicating that a well-developed porous structure formed at the higher pyrolysis temperatures. The pore volumes of the biochars were $0.177,0.164,0.038$, and 0.023 $\mathrm{cm}^{3} / \mathrm{g}$ for TBC- 800 , TBC-700, TBC- 600 , and TBC-500, respectively. The mean pore sizes of the biochars were 1.50, 3.24, 40.0, and $51.2 \mathrm{~nm}$ for TBC-800, TBC-700, TBC-600, and TBC-500, respectively. The pore diameter indicated that microspores and mesospores were the main porous structures in the biochars. These results suggest that the BET surfaces depended on the pyrolysis temperature because surface area increased with rising pyrolysis temperature. In the current study, the adsorption of $\mathrm{Cu}^{2+}$ ions improved at higher pyrolysis temperatures of 500 to $800{ }^{\circ} \mathrm{C}$, which may have been due to the increase in the BET surface area.
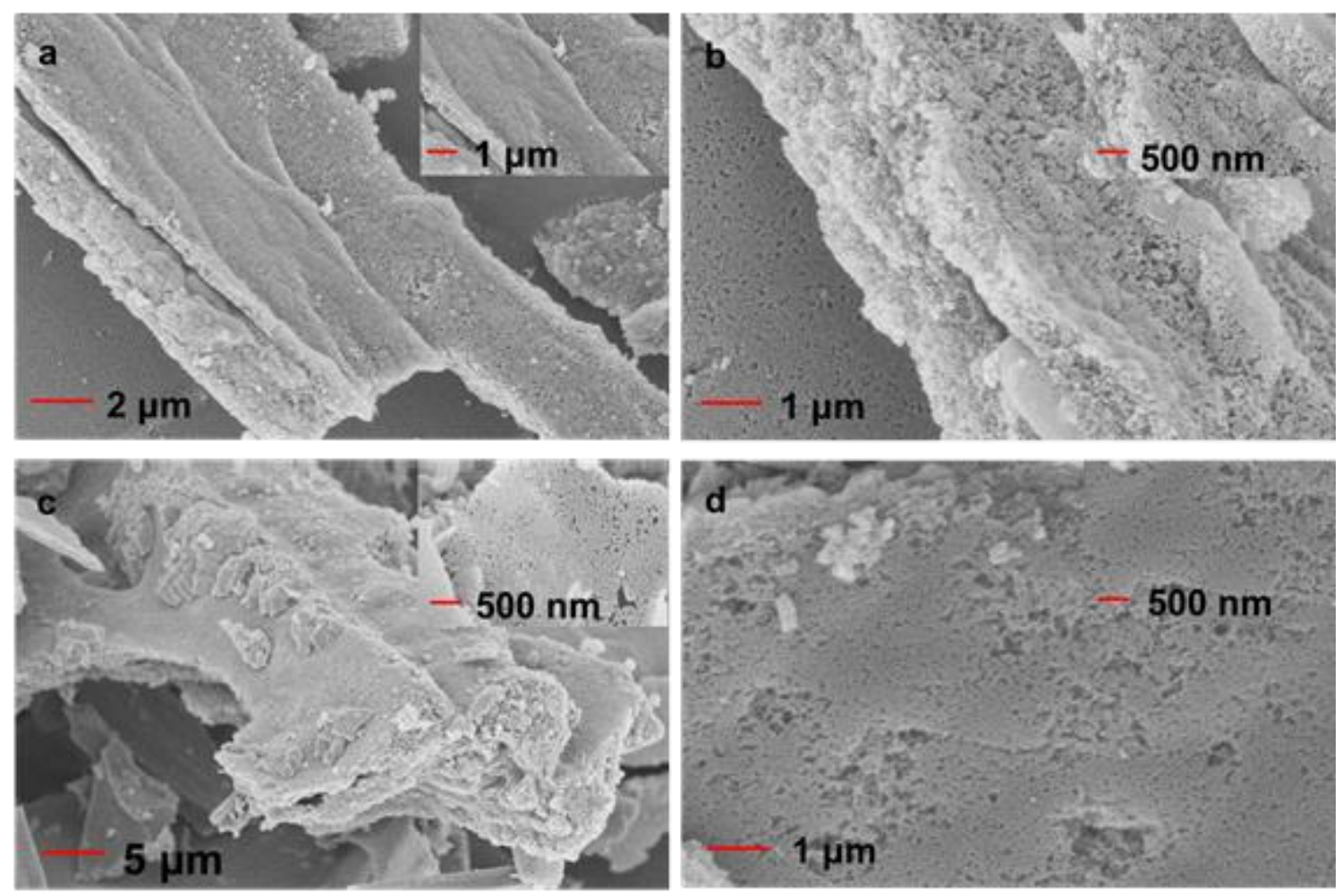

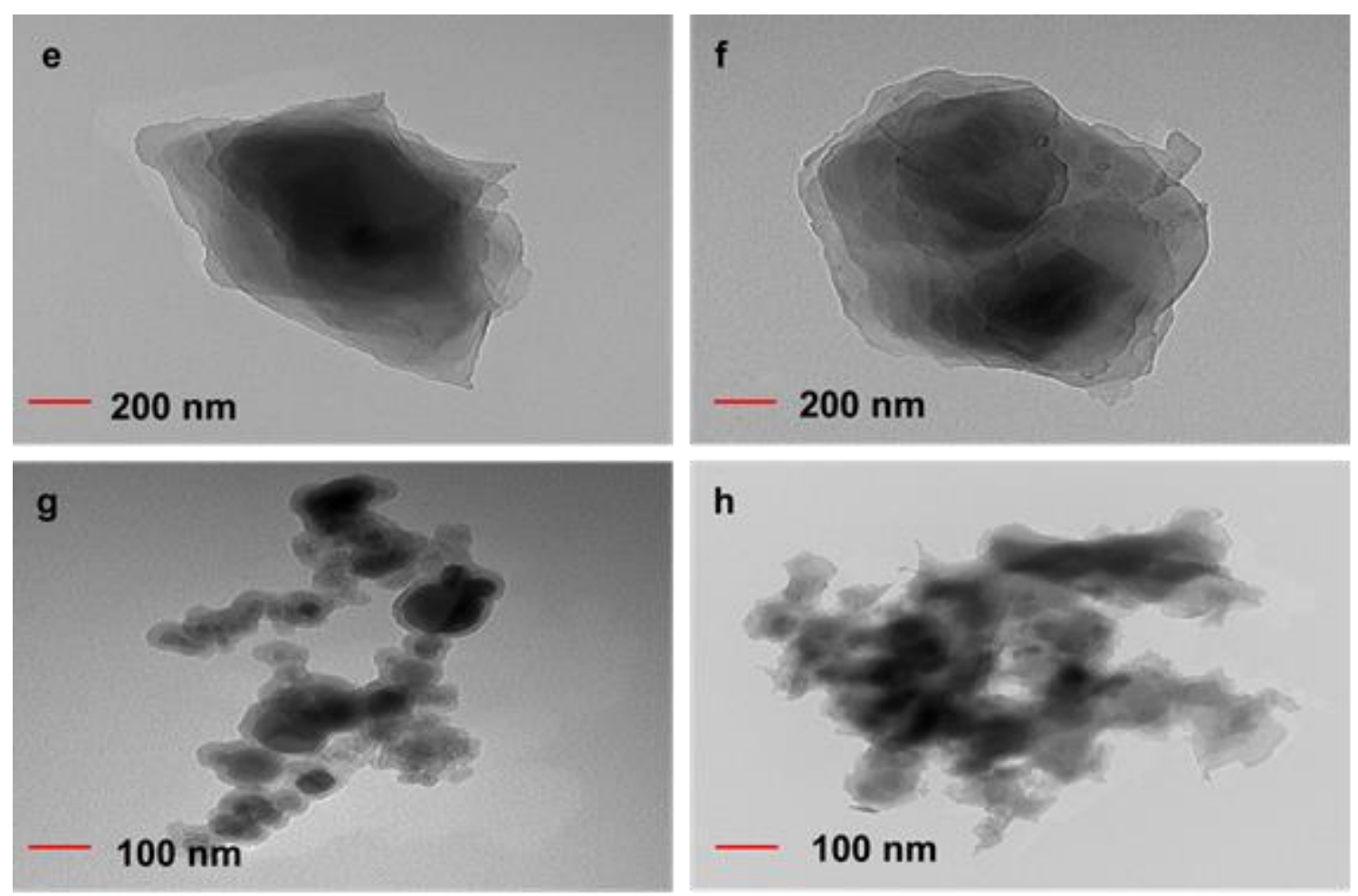

Fig. 1. SEM (a through d) and TEM (e through $h$ ) images of the biochars 

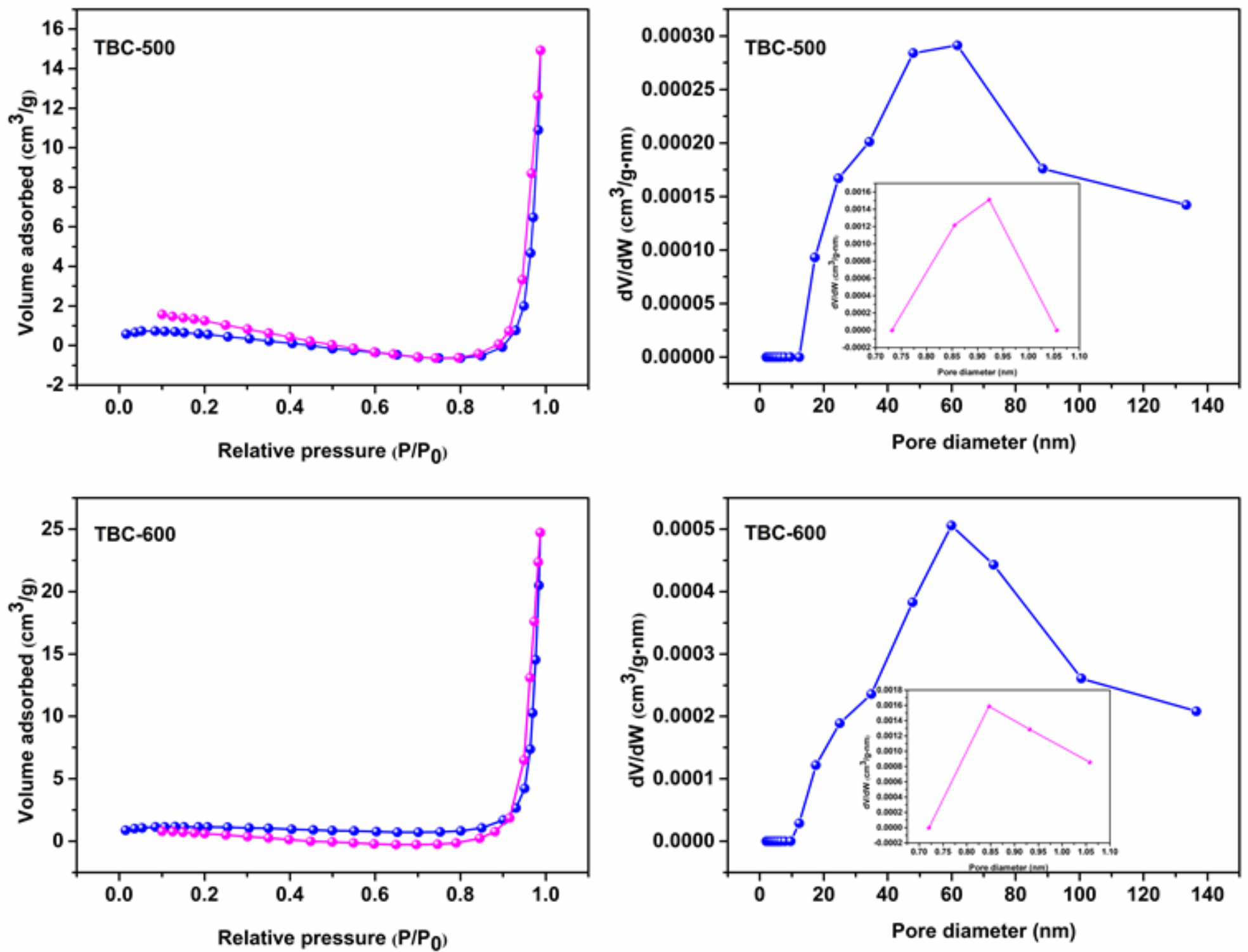

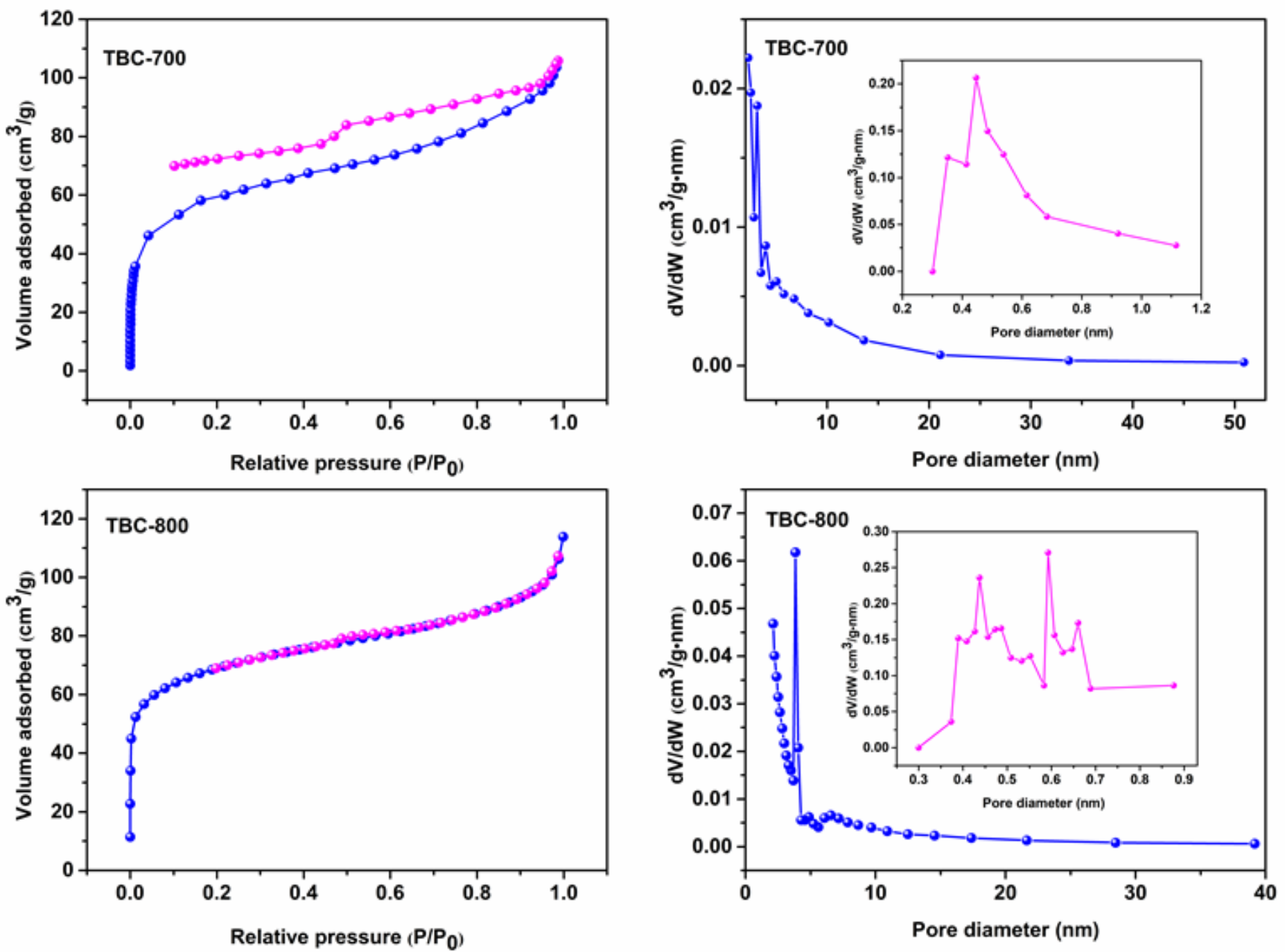

Fig. 2. Nitrogen adsorption-desorption isotherms and pore size distribution of the biochars 
The elemental compositions of the biochars are listed in Table 1. The carbon contents of TBC-500, TBC-600, TBC-700, and TBC-800 were 65.6, 67.4, 68.8, and $76.2 \%$, respectively. Carbon content increased, whereas hydrogen, oxygen, and nitrogen contents decreased, resulting in a decrease in the $\mathrm{H} / \mathrm{C}, \mathrm{O} / \mathrm{C}, \mathrm{N} / \mathrm{C}$, and $(\mathrm{N}+\mathrm{O}) / \mathrm{C}$ molar ratios (due to high carbonization and removal of polar functional groups). The $\mathrm{O} / \mathrm{C}$ ratio was lower, suggesting that the TBC surface became less hydrophilic at higher temperatures. The polarity index indicator $((\mathrm{N}+\mathrm{O}) / \mathrm{C})$ decreased, which was attributed to the formation of aromatic structures by higher carbonization of the TBC and removal of polar surface functional groups. The $\mathrm{N}$ content of TBC only depended on feedstock characteristics and not on pyrolysis temperature.

The physicochemical characteristics of the four biochars are shown in Table 1. The $\mathrm{pH}$ of the biochars increased slowly from 10.3 to 10.9 when the pyrolysis temperature was increased from 500 to $800{ }^{\circ} \mathrm{C}$. Other studies have reported that a high biochar $\mathrm{pH}$ was obtained with a higher pyrolysis temperature (Chen et al. 2011). Cellulose and hemicellulose decompose at 200 to $300{ }^{\circ} \mathrm{C}$ to produce organic acids and phenolic compounds that decrease the $\mathrm{pH}$ of biochars (Rangabhashiyam and Balasubramanian 2019). Alkali salts are released from the pyrolytic structure when the pyrolysis temperature and $\mathrm{pH}$ of the biochar are higher (Goswami et al. 2016).

Table 1. Physicochemical Characteristics of the Four Biochars

\begin{tabular}{|c|c|c|c|c|}
\hline Biochar & TBC-800 & TBC-700 & TBC-600 & TBC-500 \\
\hline $\mathrm{pH}$ & 10.86 & 10.45 & 10.30 & 10.26 \\
\hline $\mathrm{C}(\%)$ & $76.25 \pm 0.05$ & $68.83 \pm 0.03$ & $67.37 \pm 0.05$ & $65.59 \pm 0.04$ \\
\hline $\mathrm{N}(\%)$ & $0.58 \pm 0.002$ & $0.35 \pm 0.003$ & $0.38 \pm 0.01$ & $0.39 \pm 0.005$ \\
\hline $\mathrm{H}(\%)$ & $1.40 \pm 0.07$ & $1.78 \pm 0.03$ & $2.26 \pm 0.01$ & $3.19 \pm 0.02$ \\
\hline $\mathrm{O}(\%)$ & $2.19 \pm 0.15$ & $11.84 \pm 0.14$ & $13.24 \pm 0.09$ & $15.37 \pm 0.11$ \\
\hline $\mathrm{H} / \mathrm{C}$ & $0.018 \pm 0.01$ & $0.025 \pm 0.007$ & $0.033 \pm 0.006$ & $0.049 \pm 0.01$ \\
\hline $\mathrm{N} / \mathrm{C}$ & $7.6 \pm 0.01 \times 10^{-3}$ & $5.1 \pm 0.01 \times 10^{-3}$ & $5.6 \pm 0.01 \times 10^{-3}$ & $5.9 \pm 0.01 \times 10^{-3}$ \\
\hline $\mathrm{O} / \mathrm{C}$ & $0.03 \pm 0.004$ & $0.17 \pm 0.005$ & $0.19 \pm 0.008$ & $0.23 \pm 0.005$ \\
\hline $\mathrm{N}+\mathrm{O}) / \mathrm{C}$ & $0.04 \pm 0.003$ & $0.18 \pm 0.009$ & $0.20 \pm 0.003$ & $0.24 \pm 0.002$ \\
\hline $\mathrm{Ca}(\mathrm{mg} / \mathrm{kg})$ & $8.40 \pm 0.1 \times 10^{4}$ & $8.36 \pm 0.1 \times 10^{4}$ & $8.04 \pm 0.3 \times 10^{4}$ & $3.85 \pm 0.4 \times 10^{4}$ \\
\hline $\mathrm{Mg}(\mathrm{mg} / \mathrm{kg})$ & $3.52 \pm 0.1 \times 10^{3}$ & $3.38 \pm 0.1 \times 10^{3}$ & $3.04 \pm 0.1 \times 10^{3}$ & $2.67 \pm 0.1 \times 10^{3}$ \\
\hline $\mathrm{Fe}(\mathrm{mg} / \mathrm{kg})$ & $3.37 \pm 0.2 \times 10^{2}$ & $3.13 \pm 0.4 \times 10^{2}$ & $2.65 \pm 0.1 \times 10^{2}$ & $1.52 \pm 0.1 \times 10^{2}$ \\
\hline $\mathrm{K}(\mathrm{mg} / \mathrm{kg})$ & $1.15 \pm 0.2 \times 10^{4}$ & $1.06 \pm 0.1 \times 10^{4}$ & $1.09 \pm 0.1 \times 10^{4}$ & $7.79 \pm 0.1 \times 10^{3}$ \\
\hline $\mathrm{Cu}(\mathrm{mg} / \mathrm{kg})$ & $3.65 \pm 0.03 \times 10$ & $3.61 \pm 0.05 \times 10$ & $2.97 \pm 0.1 \times 10$ & $3.55 \pm 0.03 \times 10$ \\
\hline $\mathrm{Mn}(\mathrm{mg} / \mathrm{kg})$ & $4.77 \pm 0.1 \times 10$ & $4.56 \pm 0.3 \times 10$ & $4.52 \pm 0.2 \times 10$ & $3.33 \pm 0.3 \times 10$ \\
\hline $\mathrm{Zn}(\mathrm{mg} / \mathrm{kg})$ & $2.57 \pm 0.04 \times 10$ & $6.09 \pm 0.08 \times 10$ & $8.45 \pm 0.05 \times 10$ & $6.54 \pm 0.1 \times 10$ \\
\hline $\mathrm{SBET}\left(\mathrm{m}^{2} / \mathrm{g}\right)$ & 236.41 & 202.27 & 3.82 & 1.81 \\
\hline $\mathrm{Ash}(\%)$ & $19.58 \pm 0.05$ & $17.20 \pm 0.06$ & $16.75 \pm 0.03$ & $15.46 \pm 0.05$ \\
\hline
\end{tabular}

The ash contents of TBC-500, TBC-600, TBC-700, and TBC-800 were 15.5, 16.8, 17.2, and $19.6 \%$, respectively. Ash content depends on the pyrolysis temperature. The mineral elemental contents of the biochars were also investigated with the elements of interest being $\mathrm{Ca}, \mathrm{Mg}, \mathrm{Fe}, \mathrm{K}, \mathrm{Cu}, \mathrm{Mn}$, and $\mathrm{Zn}$. Calcium and potassium contents were significantly higher than the other mineral elements. The abundance of $\mathrm{Ca}$ was attributed to low organic matter. Furthermore, the abundant mineral elements provided many ion exchange sites between $\mathrm{Cu}$ and the cations $\left(\mathrm{Ca}^{2+}, \mathrm{K}^{+}\right.$, and $\left.\mathrm{Mg}^{2+}\right)$ during adsorption of $\mathrm{Cu}^{2+}$ ions which allowed the adsorption to take place at a higher rate. The $\mathrm{Cu}, \mathrm{Mn}$, and $\mathrm{Zn}$ contents of all biochars were lower than the other mineral elements; thus, they were considered negligible with respect to the adsorption experiments. 


\section{FTIR Analysis}

The surface functional groups on the TBC from different pyrolysis conditions were detected by FT-IR. Figure 6a shows that the TBC had a wide band at about 3,447 $\mathrm{cm}^{-1}$, which was assigned to the $\mathrm{O}-\mathrm{H}$ vibrations of the hydroxyl groups (Aran et al. 2016; Vyavahare et al. 2018). The absorption peak at $2,921 \mathrm{~cm}^{-1}$ was attributable to the $-\mathrm{CH}_{2}$ groups of aliphatic components (Aran et al. 2016). The peak at $1,579 \mathrm{~cm}^{-1}$ corresponded to the antisymmetric stretching vibrations of $-\mathrm{COOH}$ (Tong et al. 2011). The four types of biochars had a similar particularly intense infrared absorption band at $1,433 \mathrm{~cm}^{-1}$, which was attributed to in-plane bending of the carbonyl (-COH) groups. (Yuan et al. 2011). The intensity of the peak at $1,433 \mathrm{~cm}^{-1}$ increased with increasing pyrolysis temperature, suggesting the presence of carbonate in the biochars (Aran et al. 2016). The peak at 1,700 $\mathrm{cm}^{-1}$ was attributed to $\mathrm{C}=\mathrm{O}$ bonds from cellulose and lignin in TBC-500 (Petrovic et al. 2016). The number of functional groups on the surfaces of the biochars decreased during pyrolysis under increasing temperature and differed distinctly from those on the feedstocks. A peak at $1,262 \mathrm{~cm}^{-1}$ was assigned to phenolic -OH stretching (Chen et al. 2011; Ding et al. 2016). Bands at 874, 812, and $751 \mathrm{~cm}^{-1}$ corresponded to aromatic C-H banding (Aran et al. 2016; Ding et al. 2016). The FT-IR spectral results indicated fewer polar functional groups on the TBC, which was consistent with the elemental analysis.

\section{X-ray Diffraction Analysis}

The XRD spectra of the biochars produced at different pyrolysis temperatures are shown in Fig. 3. The cellulose crystalline structure was totally destroyed due to the high temperature. All biochars in the present study revealed a similar graphitic and inorganic structure. The diffraction peaks between $15^{\circ}$ and $30^{\circ} 2 \theta$ in the biochars were attributed to aromatic carbons. The peak at $29.50^{\circ} 2 \theta$ provided evidence for the presence of calcite $\left(\mathrm{CaCO}_{3}\right)$ in all of the biochars (Yuan et al. 2011). The FT-IR spectral and elemental analyses were further supported by the XRD pattern. The peak intensity at $29.5^{\circ} 2 \theta$ increased as pyrolysis temperature was increased from 500 to $800{ }^{\circ} \mathrm{C}$, indicating that the calcite content of the biochar increased with increasing pyrolysis temperature which was consistent with the change in peak intensity at $1,433 \mathrm{~cm}^{-1}$ in the FT-IR and elemental analyses. The presence of calcite was consistent with the alkalinity of the biochars. Moreover, the intense sharp peak at $29.5^{\circ} 2 \theta$ suggested that the calcite was well crystallized. The peaks at $28.5^{\circ}$ and $40.9^{\circ} 2 \theta$ provided evidence for the presence of $\mathrm{KCl}$ in the biochars (Wang et al. 2016). A few crystalline substances, such as magnesium calcite $\left(\mathrm{MgCO}_{3}\right)$, calcium oxalate $\left(\mathrm{CaC}_{2} \mathrm{O}_{4}\right)$, and dolomite $\left(\mathrm{Ca} / \mathrm{Mg}\left(\mathrm{CO}_{3}\right)_{2}\right)$, appeared in the biochars. The XRD analysis was consistent with the elemental analysis. 


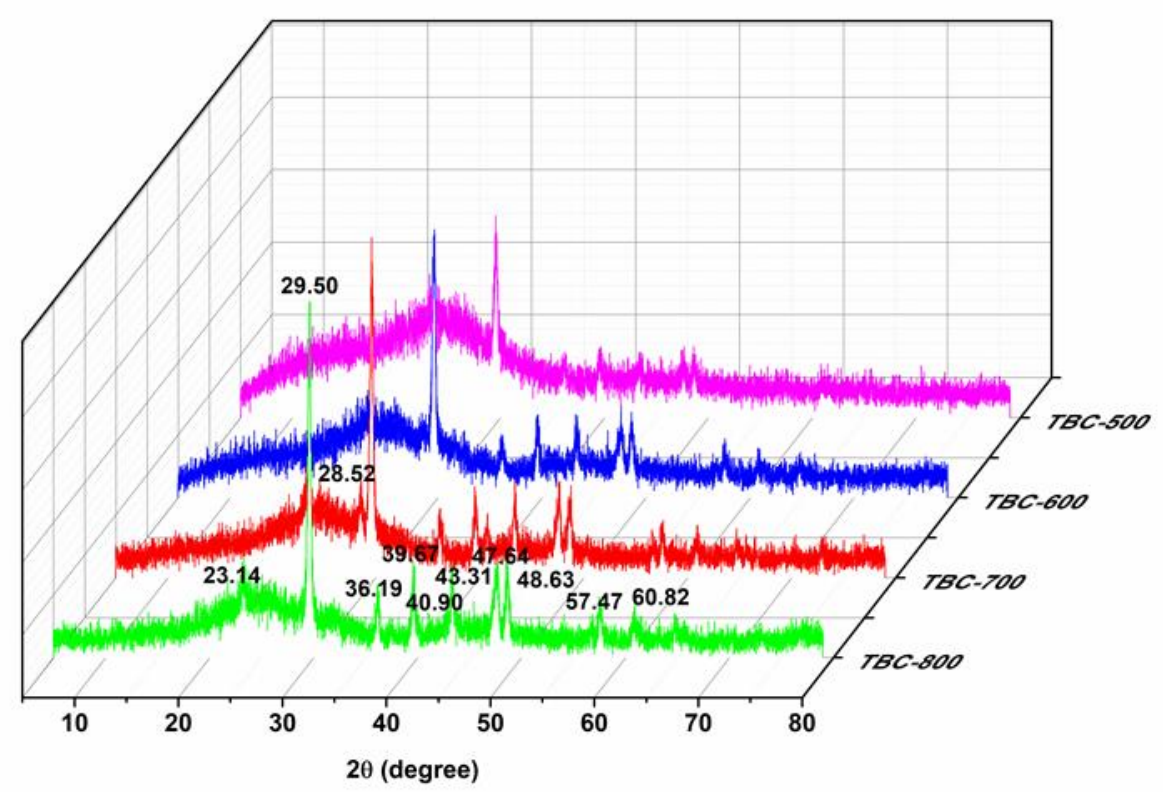

Fig. 3. The X-ray diffraction spectra for the biochars produced from T. papyriferum at different pyrolysis temperatures

\section{Effect of $\mathrm{pH}$ on the Adsorption of $\mathrm{Cu}^{2+}$ Ions}

The initial $\mathrm{pH}$ of a solution is an important factor in adsorption. The $\mathrm{pH}$ was selected in the range of 2.0 to 5.0 to avoid formation of a $\mathrm{Cu}(\mathrm{OH})_{2}$ precipitate. The results indicated that the adsorption capacity of all four biochars increased as the $\mathrm{pH}$ was increased from 2.0 to 5.0 (Fig. 4g), indicating a low adsorption capacity at $\mathrm{pH} 2.0$. These results can be explained by the competition of a large number of hydrogen and $\mathrm{Cu}^{2+}$ ions for adsorption sites on the biochars at a lower $\mathrm{pH}$ (Chen et al. 2011). Hence, all subsequent experiments in this study were carried out at the optimum initial $\mathrm{pH}$ value of 5.0 where maximum adsorption was obtained.

\section{Adsorption Kinetics}

The effect of contact time on the adsorption capacity of the biochars is shown in Fig. 4a. All experiments used $100 \mathrm{mg} / \mathrm{L} \mathrm{Cu}{ }^{2+}$ under constant stirring at $180 \mathrm{rpm}$ and temperature set to $30{ }^{\circ} \mathrm{C}$. Sorption was rapid during the first $20 \mathrm{~min}$ and reached equilibrium within $60 \mathrm{~min}$ for all biochars, showing efficient adsorption. This rapid adsorption rate at the initial stage of adsorption was attributed to the high surface area and the presence of a large number of available adsorption sites on the biochars at this stage. The rate of adsorption was faster than other materials in the biochars, as reported in previous studies (Chen et al. 2011; Pellera et al. 2012; Kılıç et al. 2013). The rate of decreased adsorption may be due to the progressive saturation of these active sites (Pellera et al. 2012). A different adsorption equilibrium time suggested that pyrolysis temperature played an important role in controlling the adsorption kinetics.

In this study, two adsorption kinetic models were studied to identify the mechanism controlling the adsorption process of $\mathrm{Cu}^{2+}$ ions on the biochars. The pseudo-first-order and pseudo-second-order kinetics models were analyzed in this study (Xiao et al. 2017). 
The equation for the pseudo-first-order kinetics model can be expressed as:

$$
\left(1 / Q_{t}\right)=\left(\mathrm{K}_{1} /\left(Q_{e} t\right)\right)+\left(1 / Q_{e}\right)
$$

The equation for the pseudo-second-order kinetics model is,

$$
\left(t / Q_{t}\right)=\left(1 /\left(\mathrm{K}_{2} Q_{e}{ }^{2}\right)\right)+\left(t / Q_{e}\right)
$$

where $Q_{e}$ and $Q_{t}(\mathrm{mg} / \mathrm{g})$ are the amount of $\mathrm{Cu}^{2+}$ ions adsorbed at equilibrium and at time $t$ (min), $K_{1}\left(\mathrm{~min}^{-1}\right)$ represents the pseudo-first-order rate constant, and $K_{2}\left(\mathrm{~g} \cdot \mathrm{mg}^{-1} \cdot \mathrm{min}^{-1}\right)$ represents the pseudo-second-order adsorption rate constant.

The linear fitting results of the pseudo-first-order and pseudo-second-order kinetic models are displayed in Fig. 4 (c and d), and the adsorption kinetics parameters are summarized in Table 2. High coefficients of determination $\left(R^{2}>0.99\right)$ were obtained for all biochars with the pseudo-second-order model. Moreover, the equilibrium adsorption capacities calculated by the pseudo-second-order model were consistent with the experimental results.

Table 2. Adsorption Kinetics Parameters for the Adsorption of $\mathrm{Cu}^{2+}$ Ions (100 $\mathrm{mg} / \mathrm{L}$ ) on the Biochars

\begin{tabular}{|c|c|c|c|c|c|c|}
\hline \multirow{2}{*}{ Biochar } & \multicolumn{3}{|c|}{ Pseudo-first-order } & \multicolumn{3}{c|}{ Pseudo-second-order } \\
\cline { 2 - 7 } & $Q_{\mathrm{e}}(\mathrm{mg} / \mathrm{g})$ & $K_{1}\left(\mathrm{~min}^{-1}\right)$ & $\mathrm{R}^{2}$ & $Q_{\mathrm{e}}(\mathrm{mg} / \mathrm{g})$ & $K_{2}\left(\mathrm{~g} \cdot \mathrm{mg}^{-1} \cdot \mathrm{min}^{-1}\right)$ & $\mathrm{R}^{2}$ \\
\hline TBC-800 & 40.7664 & 6.0881 & 0.9705 & 39.6983 & 0.0052 & 0.9992 \\
\hline TBC-700 & 39.8565 & 3.6242 & 0.9133 & 39.0472 & 0.0097 & 0.9991 \\
\hline TBC-600 & 43.2152 & 11.6499 & 0.9771 & 39.9202 & 0.0033 & 0.9975 \\
\hline TBC-500 & 31.9591 & 14.0866 & 0.9546 & 28.3527 & 0.0044 & 0.9958 \\
\hline
\end{tabular}

\section{Adsorption Isotherms of $\mathrm{Cu}^{2+}$ lons on the Biochar Fractions}

The adsorption process was carried out in the range of 25 to $1,000 \mathrm{mg} / \mathrm{L}$ at $30{ }^{\circ} \mathrm{C}$ for $24 \mathrm{~h}(180 \mathrm{rpm})$ to explore the effect of initial ion concentration on adsorption. The effect of initial $\mathrm{Cu}^{2+}$ ion concentration on biochar adsorption is shown in Fig. 4b. The adsorption capacity increased with an increase in the initial $\mathrm{Cu}^{2+}$ ion concentrations at an initial $\mathrm{Cu}^{2+}$ concentration below $400 \mathrm{mg} / \mathrm{L}$, which may have been due to the high initial concentration providing a higher driving force for $\mathrm{Cu}^{2+}$ ions to overcome mass transfer resistance in solution (Zhou et al. 2017). The adsorption capacity then slowly changed as the initial $\mathrm{Cu}^{2+}$ ion concentration increased due to saturation of the available surface active sites on the biochars. The adsorption results indicate that pyrolysis temperature played an important role in adsorption capacity. The difference in the adsorption capacities of the four kinds of biochars may be due to different physicochemical contents $(\mathrm{Ca}, \mathrm{Mg}$, and $\mathrm{K})$ and BET surface areas. The adsorption capacities of the biochars derived from different temperatures were subjected to the order of TBC-800 (182 mg/g) > TBC-700 (142 mg/g) > TBC-600 (77 mg/g) > TBC-500 (50 mg/g). Thus, higher pyrolysis temperatures were favorable to produce biochars with a higher adsorption capacity of $\mathrm{Cu}^{2+}$ ions. Overall, TBC-800 showed the fastest kinetics and the highest capacity for $\mathrm{Cu}^{2+}$ ions, and it was the best sorbent among the tested biochars.

The Langmuir and Freundlich isothermal models were used to analyze the results of the equilibrium isotherms and to better understand the adsorption mechanism of $\mathrm{Cu}^{2+}$ ions on the biochars (Kim et al. 2016; Zhou et al. 2017). The Langmuir and Freundlich models were deduced from different theoretical assumptions. The Langmuir isotherm model is based on the assumption that monolayer adsorption and adsorption occur at 
specific homogeneous sites within the adsorbent. The Langmuir (Eq. 4) and Freundlich (Eq. 5) adsorption isotherm models are expressed as follows:

$$
\begin{aligned}
& \left(C_{e} / Q_{e}\right)=\left(C_{e} / Q_{\max }\right)+\left(1 /\left(\mathrm{K}_{\mathrm{L}} Q_{\max }\right)\right) \\
& \log Q_{e}=\log \mathrm{K}_{\mathrm{F}}+(1 / \mathrm{n})\left(\log C_{e}\right)
\end{aligned}
$$

where $Q_{e}$ is the equilibrium $\mathrm{Cu}^{2+}$ ion adsorption capacity $(\mathrm{mg} / \mathrm{g}), Q_{\max }$ is the maximum adsorption capacity $(\mathrm{mg} / \mathrm{g}), K_{\mathrm{L}}$ is the Langmuir constant $(\mathrm{L} / \mathrm{mg}), K_{\mathrm{F}}$ is the Freundlich constant $(\mathrm{mg} / \mathrm{g}), C_{e}$ is the equilibrium concentrations of $\mathrm{Cu}^{2+}$ ions $(\mathrm{mg} / \mathrm{L})$, and $1 / n$ is adsorption intensity (Units).

Figure 4 (e and $\mathrm{f}$ ) presents the curve fitting for the adsorption results using the Langmuir and Freundlich models; the calculated parameters are shown in Table 3. According to the $\mathrm{R}^{2}$ values of the results presented in Table 3, the Langmuir adsorption model provided the best fit for the experimental data of all biochars with $\mathrm{R}^{2}>0.99$. The model suggested the formation of a monolayer of metal ions on the surface of the biochars. The maximum adsorption capacities of the biochars were $181 \mathrm{mg} / \mathrm{g}$ (TBC-800), $132 \mathrm{mg} / \mathrm{g}$ (TBC-700), $78 \mathrm{mg} / \mathrm{g}$ (TBC-600), and $57 \mathrm{mg} / \mathrm{g}$ (TBC-500).

Table 3. Adsorption Isotherm Parameters for the Adsorption $\mathrm{Cu}^{2+}$ Ions on the Biochars

\begin{tabular}{|c|c|c|c|c|c|c|}
\hline \multirow{2}{*}{ Biochar } & \multicolumn{3}{|c|}{ Langmuir } & \multicolumn{3}{c|}{ Freundlich } \\
\cline { 2 - 7 } & $Q_{\max }(\mathrm{mg} / \mathrm{g})$ & $K_{\mathrm{L}}(\mathrm{L} / \mathrm{mg})$ & $\mathrm{R}_{\mathrm{L}}{ }^{2}$ & $K_{\mathrm{F}}(\mathrm{mg} / \mathrm{g})$ & $n$ & $\mathrm{R}_{\mathrm{F}}{ }^{2}$ \\
\hline TBC-800 & 181.1594 & 0.2395 & 0.9990 & 47.8784 & 4.4545 & 0.7323 \\
\hline TBC-700 & 132.4503 & 0.5491 & 0.9997 & 52.9529 & 5.7594 & 0.7390 \\
\hline TBC-600 & 78.3085 & 0.2054 & 0.9997 & 16.8019 & 3.1861 & 0.7835 \\
\hline TBC-500 & 57.3724 & 0.0166 & 0.9989 & 3.2252 & 2.0471 & 0.9101 \\
\hline
\end{tabular}



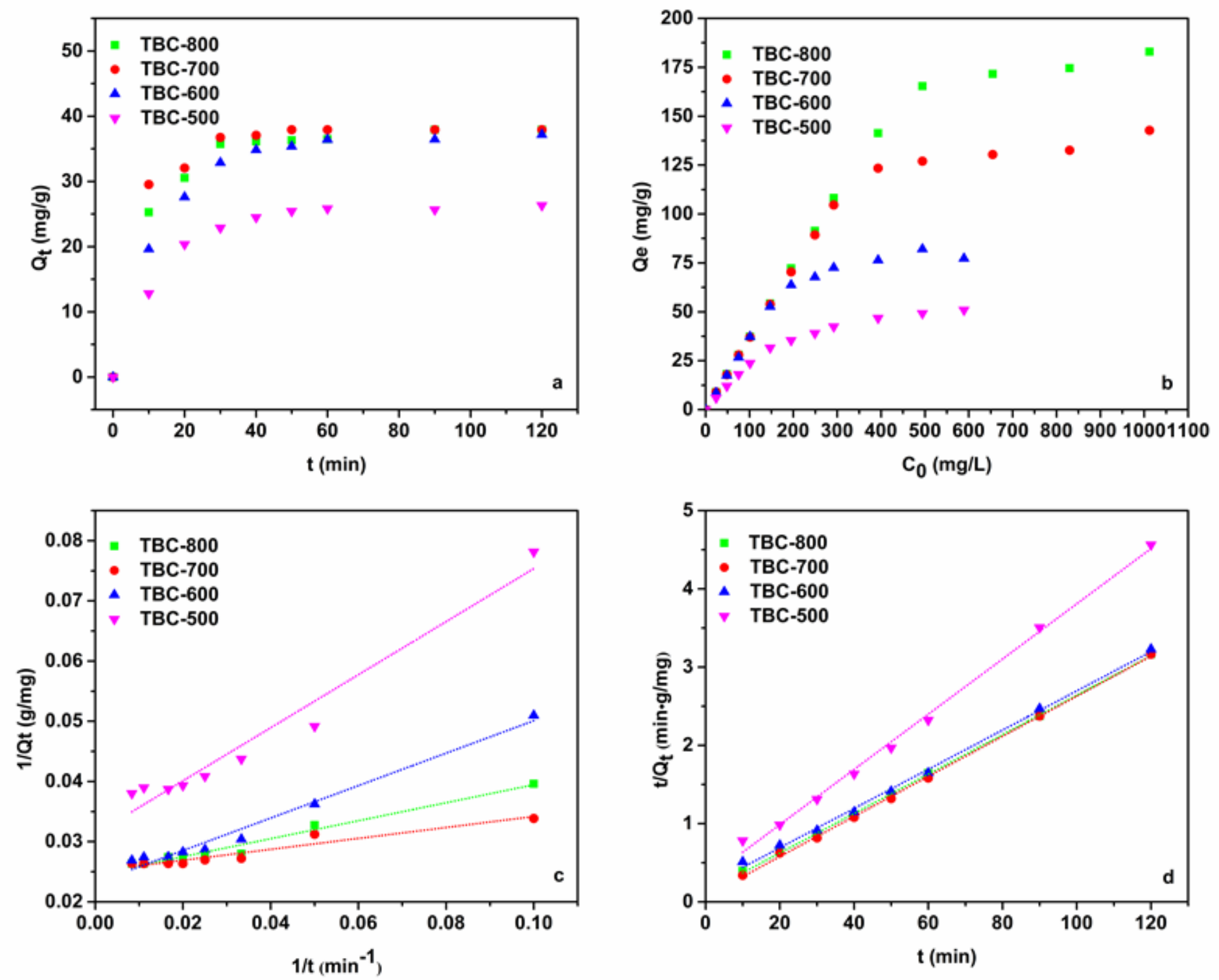


\section{bioresources.com}
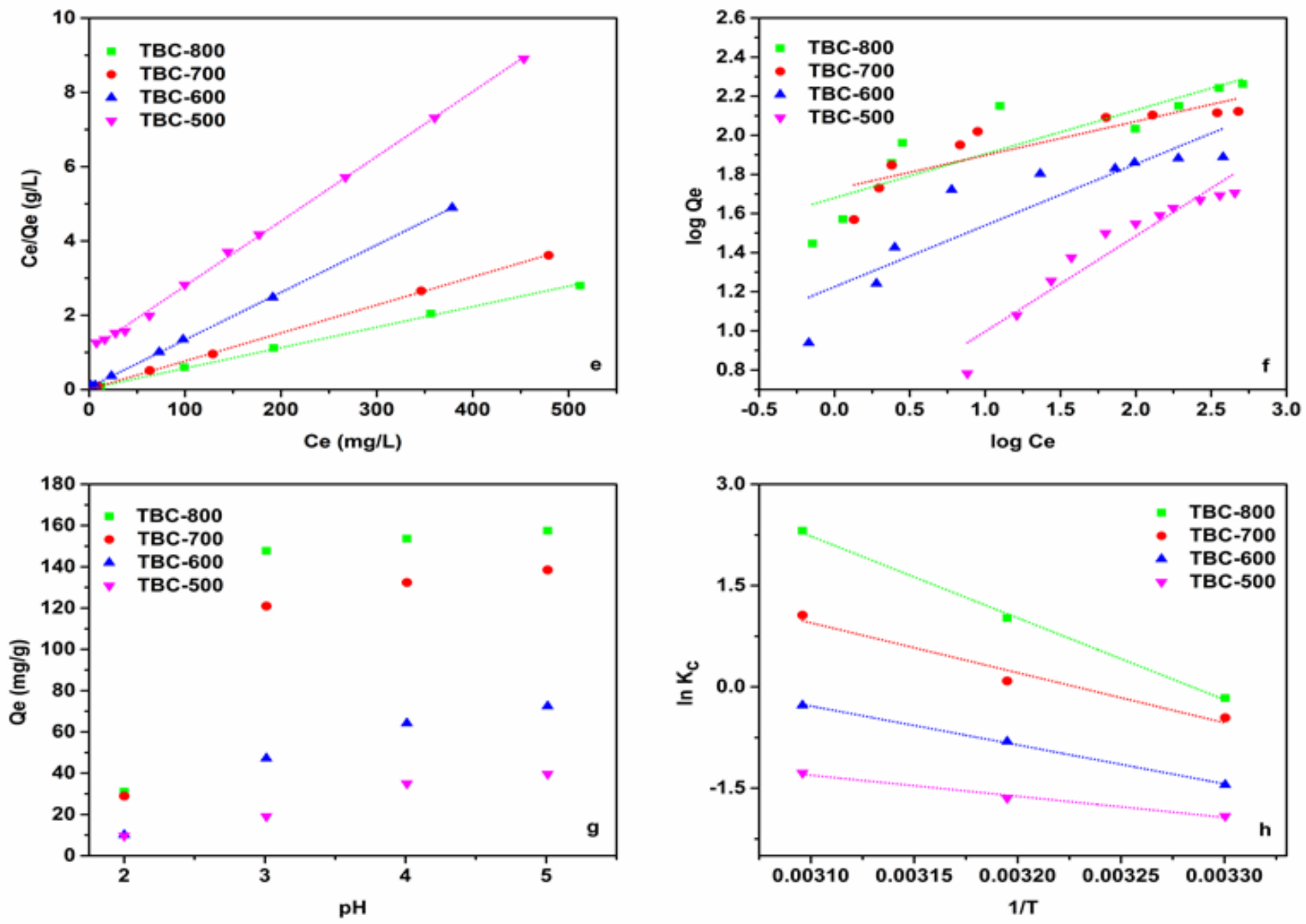

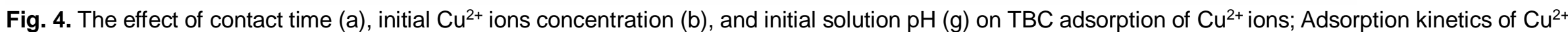
ions adsorption by linear plots of pseudo-first-order (c) and pseudo-second-order (d) rate equations on the biochars; Adsorption isotherms of Langmuir (e) and Freundlich (f) models; Van't Hoff plot $(\mathrm{h})$ for the adsorption of $\mathrm{Cu}^{2+}$ ions on the biochars 
The adsorption capacities of the biochars were compared with those reported previously in Table 4 . The maximum adsorption capacity of TBC $(181 \mathrm{mg} / \mathrm{g})$ was higher than that of the biochars produced from different biomasses including rice $(44.47 \mathrm{mg} / \mathrm{g})$, hardwood $(12.5 \mathrm{mg} / \mathrm{g})$, earthworm manure $(36.6 \mathrm{mg} / \mathrm{g})$, rice husk $(5.6 \mathrm{mg} / \mathrm{g})$, sugarcane (40.5 mg/g), peanut straw $(88.9 \mathrm{mg} / \mathrm{g})$, Undaria pinnatifida $(125.8 \mathrm{mg} / \mathrm{g}$ ), and Enteromorpha compressa $(137 \mathrm{mg} / \mathrm{g})$. Better adsorption capacity of TBC for the removal of $\mathrm{Cu}^{2+}$ was due to more active sites and higher mineral elemental contents than other adsorbents. Therefore, this study showed that TBC was a good adsorbent for removing $\mathrm{Cu}^{2+}$ ions from aqueous solution.

Table 4. Comparison of Adsorption Capacities of Biochars Reported Herein Toward Heavy Metal lons with Those Reported in the Literature

\begin{tabular}{|c|c|c|}
\hline Adsorbent (Biochar) & $\begin{array}{c}\text { Adsorption of } \mathrm{Cu}^{2+} \text { lons } \\
\text { Capacity }(\mathrm{mg} / \mathrm{g})\end{array}$ & References \\
\hline Rice & 44.5 & (Aran et al. 2016) \\
\hline Hardwood & 12.5 & (Chen et al. 2011) \\
\hline Earthworm manure & 36.6 & (Wang et al. 2017) \\
\hline Rice husk & 5.6 & (Guo et al. 2014) \\
\hline Cattle manure & 44.5 & (Idrees et al. 2018) \\
\hline Sugarcane & 40.5 & (Tass and Lima, 2018) \\
\hline Peanut straw & 88.9 & (Cho et al. 2011) \\
\hline Undaria pinnatifida & 125.8 & (Kim et al. 2016) \\
\hline Enteromorpha compressa & 137 & This work \\
\hline Tetrapanax papyriferum & 181.2 &
\end{tabular}

\section{Adsorption Thermodynamics}

The thermodynamics of adsorption of the biochars were investigated in the temperature range of 303 to $323 \mathrm{~K}$. The standard free energy change $\left(\Delta G^{\circ}\right)$, standard enthalpy change $\left(\Delta H^{\circ}\right)$, and standard entropy $\left(\Delta S^{\circ}\right)$ were calculated from the van't Hoff equation (He et al. 2017),

$$
\begin{aligned}
& \Delta G^{\circ}=-R T \ln \mathrm{K}_{c} \\
& \ln \mathrm{K}_{c}=\left(\Delta S^{\circ} / R\right)-\left(\Delta H^{\circ} / R T\right) \\
& \mathrm{K}_{c}=Q_{e} / C_{e}
\end{aligned}
$$

where $R, T$, and $\mathrm{K}_{c}$ represent the gas constant $\left(8.314 \mathrm{~J} \mathrm{~mol}^{-1} \mathrm{~K}^{-1}\right)$, the temperature in Kelvin, and the adsorption equilibrium constant, respectively. $Q_{e}(\mathrm{mg} / \mathrm{g})$ is the amount of absorbed biochar per unit mass of adsorbent at equilibrium, and $C_{e}(\mathrm{mg} / \mathrm{L})$ is the equilibrium $\mathrm{Cu}^{2+}$ ion concentration.

The adsorption capacity increased as temperature increased, indicating that adsorption is an endothermic process. The increase in temperature might provide the $\mathrm{Cu}^{2+}$ ions sufficient energy to overcome the diffuse layer and adsorb onto the interior structure of the biochars (Chen et al. 2011). The thermodynamic parameters are shown in Table 5. Negative values of $\Delta G^{\circ}$ indicate that the process was spontaneous and feasible for $\mathrm{Cu}^{2+}$ ion adsorption. The TBC-800 and TBC-700 $\Delta G^{\circ}$ values ranged from positive to negative for the adsorption of $\mathrm{Cu}^{2+}$ ions, indicating less spontaneous $\mathrm{Cu}^{2+}$ ion adsorption at lower temperatures but improved activity at higher temperatures. Moreover, the $\Delta G^{\circ}$ values decreased with the increase in temperature, indicating decreased sorption at high 
temperatures. The positive value of $\Delta H^{\circ}$ indicated that all $\mathrm{Cu}^{2+}$ ion adsorption processes on the biochars are endothermic and that higher temperatures are preferred for higher sorption. This is consistent with the observed trend in $\mathrm{Cu}^{2+}$ ion adsorption capacity. The positive $\Delta S^{\circ}$ value indicated that randomness increased at the solid/solution interface during the adsorption process.

Table 5. Adsorption Thermodynamics Parameters for the Adsorption of $\mathrm{Cu}^{2+}$ on the Biochars

\begin{tabular}{|c|c|c|c|c|c|c|}
\hline \multirow{2}{*}{ Biochar } & \multicolumn{3}{|c|}{$\Delta G^{\circ}(\mathrm{KJ} / \mathrm{mol})$} & \multirow{2}{*}{$\begin{array}{c}\Delta H^{\circ} \\
(\mathrm{KJ} / \mathrm{mol})\end{array}$} & \multirow{2}{*}{$\begin{array}{c}\Delta S^{\circ} \\
(\mathrm{J} / \mathrm{mol} / \mathrm{K})\end{array}$} & \multirow{2}{*}{$\mathrm{R}^{2}$} \\
\hline & $303 \mathrm{~K}$ & $313 \mathrm{~K}$ & $323 \mathrm{~K}$ & & & \\
\hline TBC-800 & 0.4887 & -2.8165 & -6.1217 & 100.6366 & 330.5210 & 0.9963 \\
\hline TBC-700 & 1.3430 & -0.6427 & -2.6284 & 61.5101 & 198.5711 & 0.9359 \\
\hline TBC-600 & 3.6215 & 2.1606 & 0.6998 & 47.8843 & 146.0821 & 0.9979 \\
\hline TBC-500 & 4.8706 & 4.1737 & 3.4768 & 25.9872 & 69.6917 & 0.9754 \\
\hline
\end{tabular}

\section{Reutilization Efficiency of TBC}

Testing the reuse of an adsorbent is critical for evaluating the reusability and sustainability of the adsorbent. Batch experiments were carried out to demonstrate the efficiency of TBC for adsorbing $\mathrm{Cu}^{2+}$ ions over four repeated cycles. Figure 5 shows that 99.99\% sorption of $\mathrm{Cu}^{2+}$ was observed on the TBC during the first cycle; however, sorption capacity declined to $80.4 \%$ during the fourth cycle. The overall observations showed that the TBC has the potential to be reutilized for consecutive sorption of $\mathrm{Cu}^{2+}$ ions.

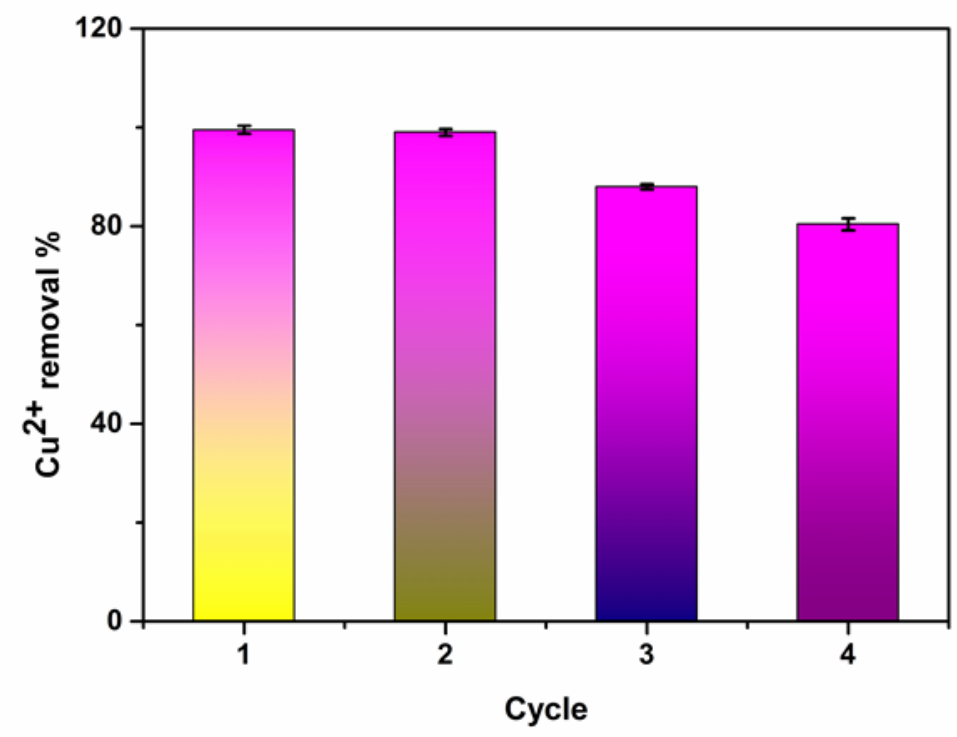

Fig. 5. Recyclability of TBC-700 for the adsorption of $\mathrm{Cu}^{2+}$ ions

\section{Adsorption Mechanism}

The FT-IR and XPS spectra were further employed to elucidate the $\mathrm{Cu}^{2+}$ ion adsorption mechanisms shown in Fig. 6. Several differences in the FT-IR spectra were observed for the TBC after $\mathrm{Cu}^{2+}$ ion adsorption. The typical bands for calcite in the TBC at about 1,440 and $875 \mathrm{~cm}^{-1}$ was decrease in intensity after the $\mathrm{Cu}^{2+}$ ions were adsorbed. This observation was in agreement with the XPS results of the elemental analysis. The 
XPS results confirmed that the atomic percentage of $\mathrm{Cu}$ increased, whereas that of $\mathrm{Ca}$ decreased after sorption, which confirmed the proposed precipitation and ion exchange mechanism. The bands assigned to $-\mathrm{OH}$ stretching vibrations at $3,441 \mathrm{~cm}^{-1}$ shifted to $3,418 \mathrm{~cm}^{-1}$, and the corresponding peaks of anti-symmetric stretching vibrations of the -COOH groups at $1,605 \mathrm{~cm}^{-1}$ for TBC-500 were shifted to $1,587 \mathrm{~cm}^{-1}$. These results are consistent with a hypothesis that the $-\mathrm{COOH}$ and phenolic hydroxyl groups reacted with $\mathrm{Cu}$ (II) to form surface complexes. The band at about $1,083 \mathrm{~cm}^{-1}$ was shifted towards 1,068 and $1,116 \mathrm{~cm}^{-1}$ due to a reduction of $\mathrm{Cu}^{2+}$ ions and formation of cuprocyanide from C-N (Batool et al. 2017). The peak at $1,687 \mathrm{~cm}^{-1}$, which was ascribed to $\mathrm{C}=\mathrm{C}$ stretching vibrations in TBC-500, disappeared after $\mathrm{Cu}^{2+}$ ion adsorption, indicating that $\pi-\pi$ interactions are involved in $\mathrm{Cu}^{2+}$ ion adsorption (Dai et al. 2018). The appearance of new peaks at $601 \mathrm{~cm}^{-1}$ and $933 \mathrm{eV}$ in the $\mathrm{Cu}$-laden $\mathrm{TBC}$ confirmed the formation of stable $\mathrm{CuO}$ (Batool et al. 2017).

TBC exhibited low surface area and higher adsorption capacity; thus, the contribution of pore filling was negligible for $\mathrm{Cu}^{2+}$ adsorption. So other adsorption mechanisms, including intraparticle diffusion, precipitation, complexation, and $\pi-\pi$ interactions might be responsible for $\mathrm{Cu}^{2+}$ removal. TBC contains a significant amount of ash (15 to 20\%). Except for $\mathrm{C}, \mathrm{H}$, and $\mathrm{N}$, other abundant mineral elements in the TCB included $\mathrm{Ca}, \mathrm{Mg}, \mathrm{Zn}, \mathrm{Cu}, \mathrm{Fe}$, and $\mathrm{Mn}$ and $\mathrm{Ca}$ was most abundant. According to the XRD and FTIR analysis, the abundant of carbonates $\left(\mathrm{CaCO}_{3}\right)$ in $\mathrm{TBC}$, a lot of research indicating heavy metals was adsorbed through the precipitation mechanism (Xu et al. 2017; Zhou et al. 2017). The bands ascribed to the calcite in the TBC at $1432 \mathrm{~cm}^{-1}$ was decreased after $\mathrm{Cu}^{2+}$ ion adsorption, which was consistent with the intensities of the peaks about $\mathrm{Ca}_{2 \mathrm{p}}$ at $348 \mathrm{eV}$ in XPS spectra. These results suggested that the precipitation interaction was related to carbonate in the TBC. The XPS results confirmed that the atomic percentage of the $\mathrm{Cu}$ was increased, whereas the $\mathrm{Ca}$ was decreased after sorption, which was confirming the proposed precipitation and ion exchange mechanism. The new peaks at $601 \mathrm{~cm}^{-1}$ and $933 \mathrm{eV}$ in the Cu-laden TBC confirmed the formation of stable $\mathrm{CuO}$ (Idrees et al. 2018). Except the precipitation mechanism, the FTIR analysis has proved the surface complexation and $\pi-\pi$ interactions mechanism. These results indicate that the $-\mathrm{COOH},-\mathrm{OH}$ and phenolic hydroxyl groups reacted with $\mathrm{Cu}$ (II) to form surface complexes. In summary, precipitation, surface complexation and $\pi-\pi$ interactions were involved in the extraordinarily adsorption of $\mathrm{Cu}^{2+}$ onto TBC. 


\section{bioresources.com}
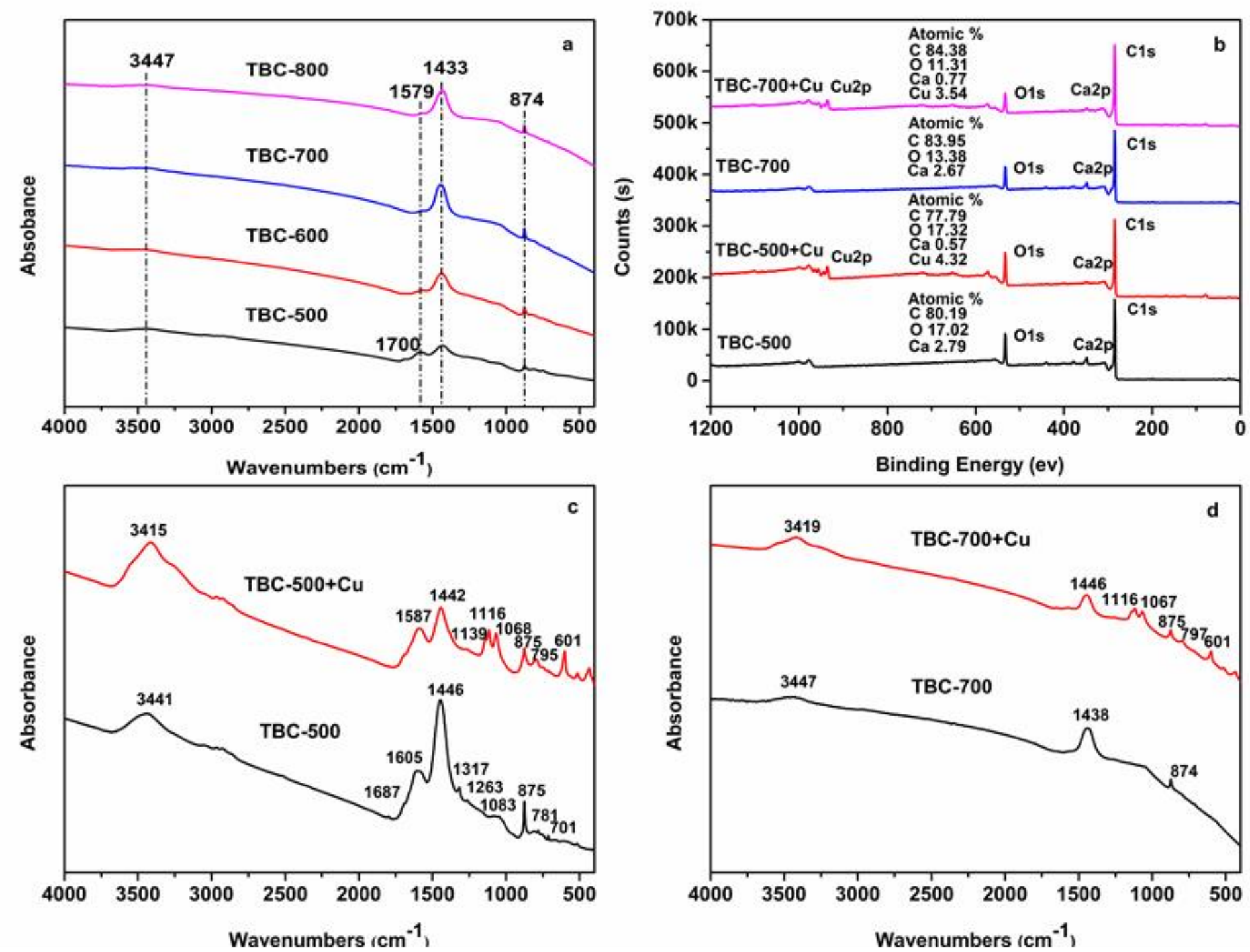

Fig. 6. FTIR spectra of the biochars (a), X-ray photoelectron spectra (b), FTIR spectra of TBC-500 (c), and TBC-700 (d) before and after Cu² ions sorption 


\section{bioresources.com}
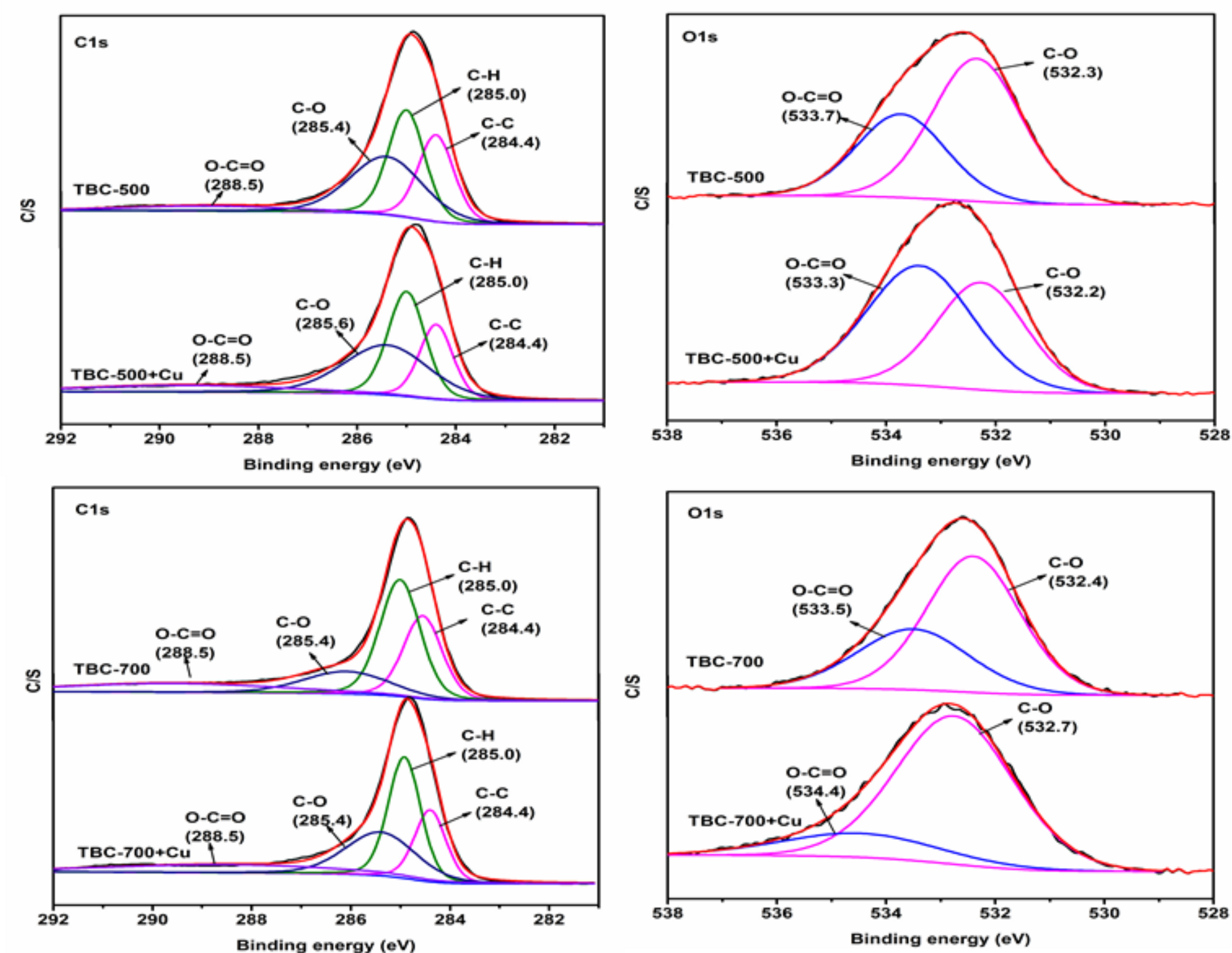

Fig. 7. High-resolution XPS spectra of $\mathrm{C}_{1 \mathrm{~s}}$ and $\mathrm{O}_{1 \mathrm{~s}}$ in TBC-500 and TBC-700 before and after $\mathrm{Cu}^{2+}$ ions sorption 
The high-resolution $\mathrm{C}_{1 \mathrm{~s}}$ and $\mathrm{O}_{1 \mathrm{~s}}$ for TBC were deconvoluted into different peaks to understand the stable chemical state after $\mathrm{Cu}^{2+}$ ion adsorption in Fig. 7. The well-fitted deconvoluted peak for $\mathrm{C}_{1 \mathrm{~s}}$ at $284.4 \pm 0.1 \mathrm{eV}$ was assigned to $\mathrm{C}-\mathrm{C}, 285.0 \pm 0.1 \mathrm{eV}$ was assigned to $\mathrm{C}-\mathrm{H}, 285.4 \pm 0.1 \mathrm{eV}$ was assigned to $\mathrm{C}-\mathrm{O}$, and $288.5 \pm 0.1 \mathrm{eV}$ was assigned to $\mathrm{O}-\mathrm{C}=\mathrm{O}$. The binding energies of $\mathrm{O}_{1 \mathrm{~s}}$ at $532.3 \mathrm{eV}$ and $533.4 \mathrm{eV}$ were assigned to $\mathrm{C}-\mathrm{O}$ and $\mathrm{O}-\mathrm{C}=\mathrm{C}$, respectively. The $\mathrm{C}_{1 \mathrm{~s}}$ and $\mathrm{O}_{1 \mathrm{~s}}$ deconvoluted peaks in the XPS spectrum were consistent with the FT-IR results. According to the percentage of atoms in XPS, the increase in pyrolysis temperature changed the surface contents of $\mathrm{C}$ and $\mathrm{O}$, but not their surface species. In summary, precipitation, ion exchange, $\mathrm{C}-\pi$ interactions, and complexation were involved in adsorption of $\mathrm{Cu}^{2+}$ ions onto TBC.

\section{CONCLUSIONS}

1. In this study, biochar (TBC) was derived from Tetrapanax papyriferum petiole by high temperature pyrolysis, and the influence of temperature $\left(500{ }^{\circ} \mathrm{C}\right.$ to $\left.800{ }^{\circ} \mathrm{C}\right)$ on biochar characteristics was investigated.

2. The surface area, mineral elements, and adsorption capacity of the resulting biochars were significantly affected by pyrolysis temperature.

3. The TBC- 800 was the most effective for sorption of $\mathrm{Cu}^{2+}$ ions with a total of 182 $\mathrm{mg} / \mathrm{g}$.

4. The adsorption capacity to remove $\mathrm{Cu}^{2+}$ ions remained high even after four adsorption cycles.

5. The adsorption process of $\mathrm{Cu}^{2+}$ by $\mathrm{TBC}$ was found to be dominated by precipitation, complexation, and $\pi-\pi$ interactions.

\section{ACKNOWLEDGMENTS}

This work was supported by the Anhui Provincial Natural Science Foundation of China (1808085MC68), the Innovation Fund of Postgraduate of Anhui Agricultural University (2018yjs-16), the Anhui Provincial Training Program of Innovation and Entrepreneurship for Undergraduates (201710364066, XJC2017131 and XJDC2017156), the China Postdoctoral Science Foundation Grant (2016M601996), the Anhui Postdoctoral Science Foundation Grant (2017B157), the National Science and Technology Program of the Thirteenth Five-Year Plan Period (2017YFD0600805-1), and the key research and development project of Anhui Province (1804g07020168).

\section{REFERENCES CITED}

Aran, D., Antelo, J., Fiol, S., and Macias, F. (2016). "Influence of feedstock on the copper removal capacity of waste-derived biochars," Bioresource Technology 212, 199-206. DOI: 10.1016/j.biortech.2016.04.043

Batool, S., Idrees, M., Hussain, Q., and Kong, J. (2017). "Adsorption of copper (ii) by using derived-farmyard and poultry manure biochars: Efficiency and mechanism," 
Chemical Physics Letters 689, 190-198. DOI: 10.1016/j.cplett.2017.10.016

Chen, X., Chen, G., Chen, L., Chen, Y., Lehmann, J., McBride, M. B., and Hay, A. G. (2011). "Adsorption of copper and zinc by biochars produced from pyrolysis of hardwood and corn straw in aqueous solution," Bioresource Technology 102(19), 8877-8884. DOI: 10.1016/j.biortech.2011.06.078

Cho, H. J., Baek, K., Jeon, J. K., Park, S. H., Suh, D. J., and Park, Y.-K. (2013).

"Removal characteristics of copper by marine macro-algae-derived chars," Chemical Engineering Journal 217(1), 205-211. DOI: 10.1016/j.cej.2012.11.123

Dai, L., Zhu, W., He, L., Tan, F., Zhu, N., Zhou, Q., and Hu, G. (2018). 'Calcium-rich biochar from crab shell: An unexpected super adsorbent for dye removal," Bioresource Technology 267, 510-516. DOI: 10.1016/j.biortech.2018.07.090

Ding, Z., Wan, Y., Hu, X., Wang, S., Zimmerman, A. R., and Gao, B. (2016). "Sorption of lead and methylene blue onto hickory biochars from different pyrolysis temperatures: Importance of physicochemical properties," Journal of Industrial and Engineering Chemistry 37, 261-267. DOI: 10.1016/j.jiec.2016.03.035

Goswami, R., Shim, J., Deka, S., Kumari, D., Kataki, R., and Kumar, M. (2016). "Characterization of cadmium removal from aqueous solution by biochar produced from Ipomoea fistulosa at different pyrolytic temperatures," Ecological Engineering 97, 444-451. DOI: 10.1016/j.ecoleng.2016.10.007

Guo, Y., Tang, W., Wu, J., Huang, Z., and Dai, J. (2014). "Mechanism of Cu(II) adsorption inhibition on biochar by its aging process," Journal of Environmental Sciences 26(10), 2123-2130. DOI: 10.1016/j.jes.2014.08.012

Han, Y., Cao, X., Ouyang, X., Sohi, S. P., and Chen, J. (2016). “Adsorption kinetics of magnetic biochar derived from peanut hull on removal of $\mathrm{Cr}$ (VI) from aqueous solution: Effects of production conditions and particle size," Chemosphere 145, 336-341. DOI: 10.1016/j.chemosphere.2015.11.050

Hass, A., and Lima, I. M. (2018). "Effect of feed source and pyrolysis conditions on properties and metal sorption by sugarcane biochar," Environmental Technology \& Innovation 10, 16-26. DOI: 10.1016/j.eti.2018.01.007

He, J., Li, Y., Wang, C., Zhang, K., Lin, D., and Kong, L., Liu, J. (2017). "Rapid adsorption of $\mathrm{Pb}, \mathrm{Cu}$ and $\mathrm{Cd}$ from aqueous solutions by $\beta$-cyclodextrin polymers," Applied Surface Science 426, 29-39. DOI: 10.1016/j.apsusc.2017.07.103

Ho, J. C., Chen, C. L., and Row L. C. (2005). "Flavonoids and benzene derivatives from the flowers and fruit of Tetrapanax papyriferus," Journal of Nature Products 68, 1773-1775. DOI: 10.1021/np050185t

Idrees, M., Batool, S., Kalsoom, T., Yasmeen, S., Kalsoom, A., Raina, S., Zhuang, Q., and Kong, J. (2018). "Animal manure-derived biochars produced via fast pyrolysis for the removal of divalent copper from aqueous media," Journal of Environmental Management 213, 109-118. DOI: 10.1016/j.jenvman.2018.02.003

Kılıç, M., Kırbıyık, Ç., Çepelioğullar, Ö., and Pütün, A. E. (2013). “Adsorption of heavy metal ions from aqueous solutions by bio-char, a by-product of pyrolysis," Applied Surface Science 283, 856-862. DOI: 10.1016/j.apsusc.2013.07.033

Kim, B. S., Lee, H. W., Park, S. H., Baek, K., Jeon, J. K., Cho, H. J., Jung, S. C., Kim, S. C., and Park, Y. K. (2016). "Removal of $\mathrm{Cu}^{2+}$ by biochars derived from green macroalgae," Environmental Science and Pollution Research 23(2), 985-994. DOI: 10.1007/s11356-015-4368-z

Li, H., Dong, X., da Silva, E. B., de Oliveira, L. M., Chen, Y., and Ma, L. Q. (2017). "Mechanisms of metal sorption by biochars: Biochar characteristics and 
modifications," Chemosphere 178, 466-478. DOI:

10.1016/j.chemosphere.2017.03.072

Lin, Y., Hong, Y., Song, Q., Zhang, Z., Gao, J., and Tao, T. (2017a). "Highly efficient removal of copper ions from water using poly(acrylic acid)-grafted chitosan adsorbent," Colloid and Polymer Science 295(4), 627-635. DOI: 10.1007/s00396-017-4042-8

Lin, Y. C., Wang, H. P., Gohar, F., Ullah, M. H., Zhang, X., Xie, D. F., Fang, H., Huang, J., and Yang, J. X. (2017b). "Preparation and copper ions adsorption properties of thiosemicarbazide chitosan from squid pens," International Journal of Bioogical Macromolecules 95, 476-483. DOI: 10.1016/j.ijbiomac.2016.11.085

Mishra, V., Majumder, C. B., and Agarwal, V. K. (2012). "Sorption of Zn(II) ion onto the surface of activated carbon derived from eucalyptus bark saw dust from industrial wastewater: isotherm, kinetics, mechanistic modeling, and thermodynamics," Desalination \&Water Treatment 46(1-3), 332-351. DOI: 10.1080/19443994.2012.677556

Niu, Y., Li, K., Ying, D., Wang, Y., and Jia, J. (2017). "Novel recyclable adsorbent for the removal of copper(II) and lead(II) from aqueous solution," Bioresource Technology 229, 63-68. DOI: 10.1016/j.biortech.2017.01.007

Park, J. H., Ok, Y. S., Kim, S. H., Cho, J. S., Heo, J. S., Delaune, R. D., and Seo, D. C. (2016). "Competitive adsorption of heavy metals onto sesame straw biochar in aqueous solutions," Chemosphere 142, 77-83. DOI: 10.1016/j.chemosphere.2015.05.093

Pellera, F. M., Giannis, A., Kalderis, D., Anastasiadou, K., Stegmann, R., Wang, J. Y., and Gidarakos, E. (2012). "Adsorption of $\mathrm{Cu}$ (II) ions from aqueous solutions on biochars prepared from agricultural by-products," Journal of Environmental Management 96(1), 35-42. DOI: 10.1016/j.jenvman.2011.10.010

Petrovic, J. T., Stojanovic, M. D., Milojkovic, J. V., Petrovic, M. S., Sostaric, T. D., Lausevic, M. D., Mihajlovic, and M. L. (2016). "Alkali modified hydrochar of grape pomace as a perspective adsorbent of $\mathrm{Pb}^{2+}$ from aqueous solution," Journal of Environmental Management 182, 292-300. DOI: 10.1016/j.jenvman.2016.07.081

Qian, L., Zhang, W., Yan, J., Han, L., Gao, W., Liu, R., and Chen, M. (2016). "Effective removal of heavy metal by biochar colloids under different pyrolysis temperatures," Bioresource Technology 206, 217-224. DOI: 10.1016/j.biortech.2016.01.065

Rangabhashiyam, S., and Balasubramanian, P. (2019). "The potential of lignocellulosic biomass precursors for biochar production: Performance, mechanism and wastewater application-A review," Industrial Crops \& Products 128, 405-423. DOI: 10.1016/j.indcrop.2018.11.041

Ren, C., Ding, X., Li, W., Wu, H., and Yang, H. (2017). "Highly efficient adsorption of heavy metals onto novel magnetic porous composites modified with amino groups," Journal of Chemical \& Engineering Data 62, 1865-1875. DOI: 10.1021/acs.jced.7b00198

Teodoro, F. S., Adarme, O. F. H., Gil, L. F., and Gurgel, L. V. A. (2017). "Synthesis and application of a new carboxylated cellulose derivative. Part II: Removal of $\mathrm{Co}^{2+}, \mathrm{Cu}^{2+}$ and $\mathrm{Ni}^{2+}$ from bicomponent spiked aqueous solution," Journal of Colloid Interface Science 487, 266-280. DOI: 10.1016/j.jcis.2016.10.043

Tong, X. J., Li, J. Y., Yuan, J. H., and Xu, R. K. (2011). “Adsorption of Cu(II) by biochars generated from three crop straws," Chemical Engineering Journal 172(2-3), 828-834. DOI: $10.1016 /$ j.cej.2011.06.069 
Vyavahare, G. D., Gurav, R. G., Jadhav, P. P., Patil, R. R., Aware, C. B., and Jadhav, J. P. (2018). "Response surface methodology optimization for sorption of malachite green dye on sugarcane bagasse biochar and evaluating the residual dye for phyto and cytogenotoxicity," Chemosphere 194, 306-315. DOI: 10.1016/j.chemosphere.2017.11.180

Wang, Y. Y., Lu, H. H., Liu, Y. X., and Yang, S.-M. (2016). “Ammonium citrate-modified biochar: An adsorbent for La(III) ions from aqueous solution," Colloids and Surfaces A: Physicochemical and Engineering Aspects 509, 550-563. DOI:

10.1016/j.colsurfa.2016.09.060

Wang, Z., Shen, F., Shen, D., Jiang, Y., and Xiao, R. (2017). "Immobilization of $\mathrm{Cu}^{2+}$ and $\mathrm{Cd}^{2+}$ by earthworm manure derived biochar in acidic circumstance," Journal of Environmental Sciences 53(3), 293-300. DOI: 10.1016/j.jes.2016.05.017

Xiao, C., Liu, X., Mao, S., Zhang, L., and Lu, J. (2017). 'Sub-micron-sized polyethylenimine-modified polystyrene/ $\mathrm{Fe}_{3} \mathrm{O}_{4} /$ chitosan magnetic composites for the efficient and recyclable adsorption of Cu(II) ions," Applied Surface Science 394, 378-385. DOI: 10.1016/j.apsusc.2016.10.116

Xu, X., Hu, X., Ding, Z., Chen, Y., and Gao, B. (2017). "Waste-art-paper biochar as an effective sorbent for recovery of aqueous $\mathrm{Pb}(\mathrm{II})$ into value-added $\mathrm{PbO}$ nanoparticles," Chemical Engineering Journal 308, 863-871. DOI: 10.1016/j.cej.2016.09.122

Yuan, J. H., Xu, R. K., and Zhang, H. (2011). "The forms of alkalis in the biochar produced from crop residues at different temperatures," Bioresource Technology 102(3), 3488-3497. DOI: 10.1016/j.biortech.2010.11.018

Zhang, Q., Li, Y., Yang, Q., Chen, H., Chen, X., Jiao, T., Peng, Q. (2018a). "Distinguished $\mathrm{Cr}(\mathrm{VI})$ capture with rapid and superior capability using polydopamine microsphere: Behavior and mechanism," Journal of Hazardous Materials 342, 732-740. DOI: 10.1016/j.jhazmat.2017.08.061

Zhang, X., Fu, W., Yin, Y., Chen, Z., Qiu, R., Simonnot, M. O., and Wang, X. (2018b). "Adsorption-reduction removal of $\mathrm{Cr}$ (VI) by tobacco petiole pyrolytic biochar: Batch experiment, kinetic and mechanism studies," Bioresource Technology 268, 149-157. DOI: 10.1016/j.biortech.2018.07.125

Zhou, B., Wang, Z., Shen, D., Shen, F., Wu, C., and Xiao, R. (2017). "Low cost earthworm manure-derived carbon material for the adsorption of $\mathrm{Cu}^{2+}$ from aqueous solution: Impact of pyrolysis temperature," Ecological Engineering 98, 189-195. DOI: 10.1016/j.ecoleng.2016.10.061

Article submitted: February 12, 2019; Peer review completed: April 7, 2019; Revised version received: April 11, 2019; Accepted: April 13, 2019; Published: April 18, 2019. DOI: $10.15376 /$ biores. 14.2.4430-4453 